\title{
Allergic cutaneous reactions to systemic corticosteroids ${ }^{*}$ Reações cutâneas alérgicas a corticóides sistêmicos"
}

\author{
Raymond Ramirez $^{1} \quad$ Ronald R. Brancaccio ${ }^{2}$
}

\begin{abstract}
Contact allergic reactions to topical corticosteroids are common. Cutaneous hypersensitivity reactions to systemically administered corticosteroids might occur though less frequently. The purpose of this literature review is to examine reported cases of cutaneous reactions to systemically administered corticosteroids. The data are presented considering route of administration, type of drug, type of reaction, and testing results. Corticosteroid classifications, cross-reactions, and allergy testing methods are also discussed.

Keywords: Adrenal cortex hormones; Adrenal cortex hormones/adverse effects; Betamethasone; Hydrocortisone; Hypersensitivity; Intradermal tests; Prednisolone; Prednisone; Triamcinolone; Patch tests

Reumo: São comuns as reações alérgicas de contato a corticóides tópicos. Podem ocorrer reações cutâneas de hipersensibilidade a corticóides sistêmicos, mas são menos frequentes. O objetivo desta revisão da literatura é examinar relatos de casos de reações cutâneas a corticóides sistêmicos. Os dados apresentados levam em consideração a via de administração, tipo de medicamento, tipo de reação e resultados dos testes. A revisão discute também sobre classificações de corticóides, reações cruzadas e testes alérgicos.

Palavras-chave: Betametasona; Corticosteróides; Corticosteróides/efeitos adversos; Hidrocortisona; Hipersensibilidade; Prednisolona; Prednisona; Testes do emplastro; Testes intradérmicos; Triamcinolona
\end{abstract}

\section{ALLERGIC CUTANEOUS REACTIONS TO SYSTEMIC CORTICOSTEROIDS}

Corticosteroids are commonly used in dermatology and other medical specialties for their anti-inflammatory and immunosuppressive effects. Cutaneous hypersensitivity reactions to topical corticosteroids are a well established and relatively common phenomenon, with a reported incidence of up to 5\% in dermatitis patients. ${ }^{1,2}$ Cutaneous hypersensitivity reactions have also been reported with systemically administered corticosteroids, though much less frequently, especially in light of their widespread usage worldwide.

Cutaneous reactions to corticosteroids are usually delayed hypersensitivity reactions (type IV). ${ }^{3}$ These delayed hypersensitivity reactions occur more readily following topical exposure to corticosteroids than via other routes of administration. ${ }^{4}$ This appears to be due to the role of epidermal Langerhans cells essential for the presentation of corticosteroid haptens. ${ }^{5}$

Immediate hypersensitivity (Type I) reactions have also been reported, generally in the setting of intravenous administrations. The exact mechanism of these reactions is unclear, but an IgE-mediated mechanism is presumed. ${ }^{3}$

The intent of this article is to review the various systemic administration routes for corticosteroids, reported allergic cutaneous reactions, the most common offending agents, methods for testing for hypersensitivity, and cross reaction patterns.

\section{Reactions and methods of administration}

Corticosteroid therapies are utilized in a multitude of formulations by nearly all fields of medicine. In dermatology, corticosteroids are most commonly used

Approved by the Editorial Council and accepted for publication on 19.01.2007

D.O. Dermatology Resident Lutheran Medical Center Dept. of Dermatology Brooklyn New York, (NY), United States of America.

M.D. Clinical Professor of Dermatology Ronald O. Perelman Department of Dermatology New York University, School of Medicine New York, (NY), United States of America.

(C)2007 by Anais Brasileiros de Dermatologia 
topically. Other medical specialties, however, frequently utilize systemic formulations via oral, inhaled, and injected routes. We reviewed the relevant literature for reports of cutaneous reactions to systemically administered corticosteroids. No doubt there are other reports not captured in this review. Our intent is that the information presented in this article will provide the reader with an overview of the types of allergic cutaneous reactions to systemically administered corticosteroids.

\section{Oral}

The most common reactions to orally administered corticosteroids occurred with prednisolone (Table 1) ${ }^{6-11}$ Allergic reactions were also noted with prednisone, betamethasone, and triamcinolone, though in lesser numbers. ${ }^{12-16}$ The majority of these cutaneous reactions were widespread in their presentations, including generalized dermatitis and urticarial reactions.

Patch testing appears to have been successful as the primary tool for diagnosing allergy to orally administered corticosteroids. Further investigations, such as intradermal testing, may be required and were positive in four of the above cases.

\section{Intramuscular}

Triamcinolone acetonide is the most commonly used intramuscular corticosteroid and reactions including generalized rash and urticaria have been reported (Table 2) ${ }^{10-17}$ In one case, the diagnosis was achieved with patch testing, while the other cases required intradermal testing. Cases of reactions to methylprednisolone and hydrocortisone have also been reported. Patch testing was not, however, performed and the diagnosis was made by intradermal testing. ${ }^{18-19}$

\section{Intralesional}

Intralesional injection of corticosteroids is a commonly used tool in dermatologic practices for the treatment of keloid scars, psoriasis, acne, and other inflammatory dermatoses.

Triamcinolone is the most commonly used intralesional corticosteroid agent. Two of the reported reactions to intralesional corticosteroids were localized cutaneous reactions, although one report of a generalized reaction, a case of anaphylaxis to triamcinolone, occurred (Table 3)..$^{20-24}$

TABLE 1: Allergic reactions to oral corticosteroids

\begin{tabular}{|c|c|c|}
\hline Drug & Reactions & Testing Results \\
\hline Prednisolone & Worsening of dermatitis & + Patch Test: tixocortol pivalate, hydrocortisone \\
\hline Prednisolone & Angioedema, dermatitis & $\begin{array}{l}\text { + Patch Test: group A,C,D (prednisolone, betamethasone) } \\
\text { + Intradermal Test: hydrocortisone, prednisolone, } \\
\text { methylprednisolone }\end{array}$ \\
\hline Prednisolone & $\begin{array}{l}\text { Generalized maculopapular } \\
\text { rash }\end{array}$ & $\begin{array}{l}\text { + Patch Test: betamethasone, pivalone, hydrocortisone, } \\
\text { prednisolone, aclomethasone }\end{array}$ \\
\hline Prednisolone & Generalized erythema & + Patch Test: prednisolone, methylprednisolone \\
\hline Prednisolone & Worsening of dermatitis & $\begin{array}{l}\text { + Patch Test: tixocortol pivalate, betamethasone, clobetasol, } \\
\text { beclomethasone, fluocinolone, triamcinolone, } \\
\text { methylprednisolone, prednisolone, dexamethasone }\end{array}$ \\
\hline Prednisolone & Urticarial eruption of face & $\begin{array}{l}\text { + Intradermal Test: hydrocortisone, prednisolone, } \\
\text { dexamethasone }\end{array}$ \\
\hline Prednisone & $\begin{array}{l}\text { Generalized urticaria and } \\
\text { facial edema }\end{array}$ & + Intradermal Test: hydrocortisone acetate, methylprednisolone \\
\hline Prednisone & Generalized dermatitis & $\begin{array}{l}\text { + Patch Test: prednisone } \\
\text { +Oral Challenge: prednisone }\end{array}$ \\
\hline Betamethasone & Maculopapular rash & + Patch Test: betamethasone, dexamethasone, fluocortisone \\
\hline Triamcinolone & Papulovesicular eruption & $\begin{array}{l}\text { + Patch Test: triamcinolone, dexamethasone, desoxymethasone } \\
\text { + Intradermal Test: triamcinolone, desoxymethasone }\end{array}$ \\
\hline Triamcinolone & $\begin{array}{l}\text { Generalized erythema- } \\
\text { multiforme-like eruption }\end{array}$ & + Patch Test: budesonide, triamcinolone acetonide \\
\hline
\end{tabular}

$+=$ positive 
TABLE 2: Allergic reactions to intramuscular corticosteroids

\begin{tabular}{lll}
\hline Drug & Reactions & Testing Results \\
\hline Triamcinolone & Generalized rash & + Patch Test: multiple corticosteroids \\
Triamcinolone & Urticaria & $\begin{array}{l}\text { Patch Test: Negative } \\
+ \text { Intradermal Test: prednisone acetonide, triamcinolone } \\
\text { acetonide, dexamethasone acetate, hydrocortisone acetate }\end{array}$ \\
Methylprednisolone & Anaphylaxis & + Intradermal Test: methylprednisolone \\
Hydrocortisone & Anaphylaxis & + Intradermal Test: hydrocortisone sodium succinate \\
\hline
\end{tabular}

$+=$ positive

\section{Intravenous}

There are numerous reports of reactions to intravenous corticosteroids. ${ }^{25-36}$ of 12 cases reviewed for reactions to intravenously administered corticosteroids, 10 cases noted anaphylactic or urticarial reactions. ${ }^{25-34}$ The majority of these reactions are reported to occur with methylprednisolone and are immediate hypersensitivity reactions reported as anaphylaxis or acute worsening of preexisting asthma. Examples of these cases are listed (Table 4). Other reported cutaneous reactions were a pruritic rash and purpura to methylprednisolone and hydrocortisone. In some of the reported cases of reactions to intravenous corticosteroids, allergy testing was not performed.

\section{Inhalation (oral inhalers and nasal inhalers)}

Orally inhaled and intranasal steroids, such as budesonide, fluticosone, betamethasone, and mometasone, have become common treatment modalities for asthma and allergic rhinitis. The majority of adverse reactions reported with the use of these medications are localized. These reactions include erythema, dryness, and irritation of the nasal and oral mucosa. Such reactions may also extend to the perioral or perinasal skin and thus present to dermatology.

The three reports we reviewed noted two cases of dermatitis and one case of angioedema. Patch testing successfully diagnosed contact allergy in all three cases (Table 5). ${ }^{37-38}$

Isaksson et al reviewed 34 patients with a history of side-effects following inhaled corticosteroid use. ${ }^{39}$ These reactions included facial rash, epistaxis, urticaria, and pruritus. Of these 34 patients, however, only one patient was found to be positive on patch testing to tixocortol pivalate. This raises the possibility of other possible allergens in inhaled corticosteroids which induce cutaneous hypersensitivity reactions.

TABLE 3: Allergic reactions to intralesional corticosteroids

\begin{tabular}{|c|c|c|}
\hline Drug & Reactions & Testing Results \\
\hline Triamcinolone & Erythema and edema & $\begin{array}{l}\text { + Patch Test: budesonide, amcinonide, triamcinolone } \\
\text { + Intradermal Test: triamcinolone }\end{array}$ \\
\hline Triamcinolone & Erythema and pruritus & $\begin{array}{l}\text { + Patch Test: tixocortol pivalate, amcinonide, triamcinolone } \\
\text { acetonide, and budesonide } \\
\text { + Intradermal Test: triamcinolone acetonide }\end{array}$ \\
\hline Triamcinolone & Anaphylaxis & $\begin{array}{l}\text { Intradermal Test: negative, Patch Test: negative } \\
\text { Recurrence with rechallenge }\end{array}$ \\
\hline Betamethasone & Erythematous, pruritic rash & $\begin{array}{l}\text { + Patch Test: budesonide, amcinonide, triamcinolone acetonide, } \\
\text { hydrocortisone-17-butyrate, betamethasone-17- butyrate, } \\
\text { clobetasol-17-propionate, betamethasone }\end{array}$ \\
\hline Paramethasone & Pruritus, erythema and vesicles & $\begin{array}{l}\text { + Patch Test: tixocortol-21-pivalate, hydrocortisone-17-butyrate, } \\
\text { hydrocortisone, paramethasone acetate }\end{array}$ \\
\hline
\end{tabular}

$+=$ positive 
TABLE 4: Allergic reactions to intravenous corticosteroids

\begin{tabular}{lll}
\hline Drug & Reactions & Testing Results \\
\hline Methylprednisone & Anaphylaxis & $\begin{array}{l}\text { Patch Test: not performed } \\
+ \text { Intradermal Test: methylprednisone }\end{array}$ \\
Methylprednisone & Pruritic rash & + Patch Test: hydrocortisone and prednisone \\
Hydrocortisone & Purpura & + Intradermal Test: dexamethasone, hydrocortisone succinate, \\
& & hydrocortisone, deflazacort, prednisolone
\end{tabular}

$+=$ positive

TABLE 5: Allergic reactions to inhaled corticosteroids

\begin{tabular}{lll}
\hline Drug & Reactions & Testing Results \\
\hline Budesonide & Angioedema & + Patch and Scratch Test: budesonide \\
Budesonide & Severe rash & + Patch Test: hydrocortisone-17-butyrate and budesonide \\
Beclomethasone & Eczematous dermatitis & $\begin{array}{l}+ \text { Patch Test: betamethasone-17-valerate, hydrocortisone-17- } \\
\text { butyrate, and budesonide }\end{array}$ \\
\hline
\end{tabular}

$+=$ positive

\section{Intra-articular}

Both triamcinolone and methylprednisolone are commonly used for intra-articular corticosteroid injections, primarily for arthritis and other inflammatory arthritic disorders. The four reports we reviewed noted generalized reactions such as erythema multiforme-like dermatitis, widespread erythema, and generalized urticaria (Table 6). ${ }^{46-43}$ Allergies were confirmed in each case by patch testing, and in two of the cases, intradermal testing was also positive.

\section{Classifications of glucocorticosteroids}

Corticosteroids have been categorized into four groups (A-D) based on their stereochemistry and molecular configurations. ${ }^{44}$ These classifications have been further validated by computer conformational analysis by Lepoittevin et al. ${ }^{45} \mathrm{~A}$ further division of group D into subgroups (D1 and D2) has been proposed by Goosens et al (Table 7). ${ }^{46}$

Examples of members from each group are as follows:

\section{Cross-reactivity of corticosteroids}

In addition to hypersensitivity to a specific corticosteroid exposure, patients have been noted to be patch test positive to agents with which they have not been previously exposed. This indicates the presence of cross-reactivity between the primary offending agent and other corticosteroids. The potential for cross-reactivity exists within each of the corticos- teroid groups. Cross-reaction between groups has also been observed, though to a lesser extent. ${ }^{44}$

\section{Cross-reactions between groups: group $\mathbf{A}$ and group D2}

Corticosteroids from group D2 (hydrocortisone-17-butyrate type) have shown significant crossreactivity with other corticosteroids from within this group, as well as corticosteroids from group A (hydrocortisone type) as well as budesonide from group B. 3 Hydrocortisone-17-butyrate from group D2 is enzymatically converted to hydrocortisone of group $\mathrm{A}$ in the skin.

Likewise, methylprednisolone aceponate of group D2 is converted in several steps to methylprednisolone of group A and prednicarbate of group D2 is converted to prednisolone of group A.

Corticosteroids from group D1 (betamethasone dipropionate type) have been shown to have minimal cross-reactivity.

\section{Cross-reactions between groups: group B and group D2}

Because of the unique molecular structure of budesonide, it has shown cross-reactivity with corticosteroids of both group B and group D2. Lepoittevin et al. demonstrated budesonide crossreactivity with members of group D2 (hydrocortisone-17-butyrate, prednicarbate, alclometasone dipropionate). ${ }^{45}$ Ferguson et al. likewise demonstrat- 
TABLE 6: Allergic reactions to intra-articular corticosteroids

\begin{tabular}{|c|c|c|}
\hline Drug & Reactions & ing Results \\
\hline Triamcinolone & Erythema multiforme-like dermatitis & + Patch Test: triamcinolone acetonide, budesonide \\
\hline Triamcinolone & Generalized cutaneous eruption & $\begin{array}{l}\text { + Patch Test: triamcinolone acetonide, hydrocortisone } \\
\text { valerate, desonide, betamethasone valerate, diflorasone } \\
\text { diacetate, amcinonide, hydrocortisone butyrate, } \\
\text { budesonide, alclometasone diproprionate, clobetasol } \\
\text { propionate, and dexamethasone }\end{array}$ \\
\hline Methylprednisolone & Widespread erythema & $\begin{array}{l}\text { + Patch Test: tixocortol pivalate } \\
\text { + Intradermal Test: hydrocortisone, prednisolone, } \\
\text { methylprednisone }\end{array}$ \\
\hline Methylprednisolone & Generalized urticaria & $\begin{array}{l}\text { + Patch Test: } 21 \text { of } 26 \text { corticosteroids tested } \\
\text { + Intradermal Test: hydrocortisone, methylprednisone }\end{array}$ \\
\hline
\end{tabular}

$+=$ positive

ed budesonide cross-reactivity with hydrocortisone21-sodium phosphate and triamcinolone acetonide. Cross-reaction is therefore also expected with hydrocortisone-21-acetate, hydrocortisone-21-butyrate, and hydrocortisone-21-succinate as well. ${ }^{47}$

\section{Testing for systemic corticosteroid hypersensitivity}

Testing for hypersensitivity to systemic corticosteroids may require patch testing, intradermal testing, or both.

\section{Patch testing}

Patch testing is generally an adequate screen- ing tool to evaluate hypersensitivity to topical corticosteroids. Patch testing can detect up to $90 \%$ of corticosteroid hypersensitivities by the use of tixocortol pivalate and budesonide. ${ }^{48,49}$ Tixocortol pivalate is an effective screening marker for group A (hydrocortisone type) corticosteroids ${ }^{50}$, while budesonide is an effective marker for group B (triamcinolone acetonide type) corticosteroids. Further studies have recommended that tixocortol pivalate and budesonide be testing in a petrolatum at a concentration of $1 \%$ for optimal effect. ${ }^{51,52}$ The recommended concentrations for testing these two markers is controversial. The North American Contact Dermitis Group uses

TABle 7: Corticosteroid classes

\begin{tabular}{|c|c|c|c|c|}
\hline Group A & Group B & Group C & Group D1 & Group D2 \\
\hline $\begin{array}{l}\text { Hydrocortisone } \\
\text { type }\end{array}$ & $\begin{array}{l}\text { Triamcinolone } \\
\text { Acetonide type }\end{array}$ & Betamethasone type & $\begin{array}{l}\text { Betamethasone } \\
\text { dipropionate type }\end{array}$ & $\begin{array}{l}\text { Methylprednisolone } \\
\text { aceponate type }\end{array}$ \\
\hline Hydrocortisone & Budesonide & Betamethasone & $\begin{array}{l}\text { Beclomethasone } \\
\text { dipropionate }\end{array}$ & $\begin{array}{l}\text { Methylprednisolone } \\
\text { aceponate }\end{array}$ \\
\hline Hydrocortisone acetate & Triamcinolone & Desoxymethasone & $\begin{array}{l}\text { Betamethasone } \\
\text { dipropionate }\end{array}$ & Hydrocortisone valerate \\
\hline Methylprednisolone & Triamcinolone acetonide & Dexamethasone & $\begin{array}{l}\text { Betamethasone-17- } \\
\text { valerate }\end{array}$ & $\begin{array}{l}\text { Hydrocortisone-17- } \\
\text { butyrate }\end{array}$ \\
\hline Prednisone & Triamcinolone acetonide & Desoximetasone & Clobetasol propionate & $\begin{array}{l}\text { Hydrocortisone-17- } \\
\text { buteprate }\end{array}$ \\
\hline Prednisolone & Triamcinolone diacetate & Fluocortolone & Clobetasone butyrate & $\begin{array}{l}\text { Hydrocortisone-17- } \\
\text { aceponate }\end{array}$ \\
\hline Prednisolone caproate & Desonide & Halomethasone & Clobetasone propionate & Prednicarbate \\
\hline Prednisolone acetate & Fluocinonide & Fluprednidene acetate & Diflorasone diacetate & \\
\hline Fludrocortisone acetate & Fluocinolone acetonide & Clocortolone & Mometasone furoate & \\
\hline \multirow[t]{4}{*}{ Tixocortol pivalate } & Amcinonide & & Fluticasone & \\
\hline & Flunisolide & & Propionate & \\
\hline & Halcinonide & & Diflucortolone valerate & \\
\hline & & & $\begin{array}{l}\text { Alclometasone-17,21- } \\
\text { dipropionate }\end{array}$ & \\
\hline
\end{tabular}


concentrations of tixocortol-21-pivalate $1.0 \%$ in petrolatum and budesonide $0.1 \%$ in petrolatum.

However, the very nature of the corticosteroids' anti-inflammatory effects can make this problematic. ${ }^{53}$ The anti-inflammatory effect of a corticosteroid may mask its own patch-test reaction. In addition, there is no consensus concerning the most effective concentrations and vehicles to be used for patch testing. Concentrations that are insufficient may lead to a false-negative reading, as has been repeatedly demonstrated in cases of subsequent positive intradermal testing. Corticosteroid concentrations that are too high may lead to masking of the hypersensitivity reaction. The use of higher concentrations has been recommended for strongly suspected cases of contact allergy in spite of negative readings at the lower concentration. ${ }^{52}$

Patch testing is considered a safe option to evaluate a cutaneous reaction to a systemic medication. ${ }^{54}$ This method of re-exposure has not been studied extensively, but is a useful diagnostic tool as supported by the case reported cited in this article. For suspected allergy to systemic corticosteroids, patch testing should be performed initially. If these tests are negative, then consider performing intradermal testing to the suspected corticosteroid.

\section{Intradermal testing}

Intradermal testing is also used for the detection of allergic reactions to corticosteroids. This method may be of use in situations where inadequate percutaneous penetration of corticosteroids in patch testing may lead to false-negative results. Metabolism and binding to epidermal cells may, also, play a role in the allergic process. ${ }^{55}$ Not all formulations are available for intradermal testing.

Intradermal testing is carried out by an intracutaneous injection of the test formulation with a 0.5 to $1.0 \mathrm{ml}$ tuberculin syringe and 26 - or 27 -guage needle. A volume of $0.1 \mathrm{ml}$ is injected into the superficial dermis of the flexor aspect of the forearm and a superficial bleb of 2 to $3 \mathrm{~mm}$ diameter should be obtained. ${ }^{56}$ A $0.1 \mathrm{ml}$ intradermal injection of normal saline should be used as a control. Results should be read at 15 minutes, day 2 , and day 4 . A 5 to $10 \mathrm{~mm}$ wheal is considered to be a positive result.

Due to the limited availability of sterile commercial corticosteroid products, only a select number can be tested. These include, with their recommended concentrations ${ }^{47}$ budesonide $0.025 \%$, dexamethasone $0.4 \%$, hydrocortisone-21-sodium phosphate, methyl-prednisolone $4 \%$, and triamcinolone acetonide $4 \%$. There are no controlled studies to date comparing the above test concentrations or standardized concentrations for intradermal testing available.

Risks involved in the use of intradermal testing include atrophy, risk of sensitization, prolonged reactions, and anaphylactic reactions. Systemic reactions are infrequent but can include anaphylaxis. Some deaths have been reported. Because of the potential for serious systemic reaction, adequate emergency measures need to be present. ${ }^{56}$

\section{Oral provocation}

Chew and Maibach performed oral provocation testing on a patient with a history of a generalized maculopapular rash and patch test positivity to multiple corticosteroids. ${ }^{57}$ Oral provocations with triamcinolone, methylprednisolone, dexamethasone, and prednisone elicited a maculopapular rash. Rechallenge to the suspected systemic corticosteroid is the most definitive way of diagnosing allergy; however, challenge tests are contraindicated in severe drug reactions.

\section{CONCLUSION}

While allergic cutaneous reactions to systemically administered corticosteroids are relatively uncommon, they should be considered as possible causes for hypersensitivity reactions. When hypersensitivity to systemic corticosteroids is suspected, patch and intradermal testing should be performed. Further management of these patients requiring systemic corticosteroids (bullous dermatoses, vasculitis, connective tissue disorders) will necessitate a working knowledge of the different classes of corticosteroids, possible cross-reactions, and alternative corticosteroid choices. Awareness of these issues is important to all clinicians utilizing systemic corticosteroid therapy. 


\section{REFERÊNCIAS}

1. Dooms-Goossens A, Morren M. Results of routine patch testing with corticosteroid series in 2073 patients. Contact Dermatitis. 1992;26:182-91.

2. Matura M, Goossens A. Contact allergy to corticosteroids. Allergy. 2000;55:698-704.

3. Scheuer E, Warshaw E. Allergy to corticosteroids: update and review of epidemiology, clinical characteristics, and structural cross-reactivity. Am J Contact Derm. 2003;14:179-187.

4. Räsänen L, Hasan T. Allergy to systemic and intralesional corticosteroids. Br J Dermatol. 1993;128:407-11.

5. Lauerma AI, Reitamo S. Contact allergy to corticosteroids. J Am Acad Dermatol. 1993;28:618-22.

6. Isaksson M, Persson L-M. Contact allergy to hydrocortisone and systemic dermatitis from prednisolone with tolerance of betamethasone. Am J Contact Derm. 1998;9:136-8.

7. Bircher AJ, Levy F, Langauer S, Lepoittevin JP. Contact allergy to to topical corticosteroids and systemic contact dermatitis from prednisolone with tolerance to triamcinolone. Acta Derm Venereol (Stockh). 1995;65:490-93.

8. McKenna DB, Murphy GM. Contact allergy to topical corticosteroids and systemic allergy to prednisolone. Contact Dermatitis. 1998;38:121-22.

9. Shigemi F, Tanaka M, Ohtsula T. A case of sensitization to oral corticosteroids. J Dermatology. 1978;5:231-3.

10. English JSC, Ford G, Beck MH, Rycroft RJ. Allergic contact dermatitis from topical and systemic corticos teroids. Contact Dermatitis. 1990;23:196-7.

11. Clee MD, Ferguson J, Browning MC, Jung RT, Clark RA. Glucocortricoid hypersensitivity in an asthmatic patient. Presentation and treatment. Thorax. 1985;40:477-8.

12. Von Maur K, Rockin RE, Stevens MB. Corticosteroid allergy in patient with systemic lupus erythematosus. Hopkins Med J. 1974; 134:356-64.

13. Quirce S, Alvarez MJ, Olaguibel JM. Systemic contact dermatitis from oral prednisone. Contact Dermatitis. 1994:30:53-4.

14. Nucera E, Buonomo A, Pollastrini E, De Pasquale T, Del Ninno M, Roncallo C, et al. A case of cutaneous delayedtype allergy to oral dexamethasone and to betamethasone. Dermatology. 2002;204:248-50.

15. Brambilla L, Beonschi V, Chiappino G, Fossati S, Pigatto PD. Allergic reactions to topical desoxymethasone and oral triamcinolone. Contact Dermatitis. 1989;21:272-4.

16. Stingeni L, Caraffini S, Assalve D, Lapomarda V, Lisi P. Erythema-multiforme-like contact dermatitis from budesonide. Contact Dermatitis. 1996;34:154.

17. Murrieta-Aguttes M, Michelen V, Leynadier F, DuarteRisselin C, Halpern GM, Dry J. Systemic reactions to corticosteroids. J Asthma. 1991;154:210-4.

18. Moreno-Ancillo A, Martin-Munoz F, Martin-Barroso J-A, Diaz-Pena JM, Ojeda JA. Anaphylaxis to 6- $\alpha$-methylprednisolone in an eight-year-old child. J Allergy Clin Immunol. 1996;97:1169-71.

19. Rodger RSC. Anaphylaxis following treatment with a corticosteroid report of one case. Clin Allergy. 1983;13:499-500.

20. Brancaccio R, Zappi E. Delayed type hypersensitivity to intralesional triamcinolone acetonide. Cutis. 2000; 65:31-3.

21. Saff DM, Taylor JS, Vidimos AT. Allergic reaction to intralesional triamcinolone acetonide: a case report. Arch Derm. 1995;131:742-43.

22. Downs AMR, Lear JT, Kennedy CT. Anaphylaxis to intra dermal triamcinolone acetonide. Arch Derm. 1998; 134:1163-64.

23. Miguélez F, Mestre A, Martín J, Escalas, LJ. Del Pozo Allergic reaction to intralesional Celestone Cronodose. Br J Dermatol. 2003;149:894-6.

24. Miranda-Romero A, Bajo-Del Pozo C, SanchezSambucety P, Martinez-Fernandez M, Garcia-Munoz M. Delayed local allergic reaction to intralesional paramethasone acetate. Contact Dermatits. 1998;39:31-2.

25. Mendelson LM, Meltzer EO, Hamburger RN. Ana phylaxis-like reactions to corticosteroid therapy. J Allergy Clin Immunol. 1974;54:125-31.

26. Partridge MR, Gibson GJ. Adverse bronchial reactions to intravenous hydrocortisone in two aspirin sensitive asthmatic patients. Br Med J. 1978;1:1521-2.

27. Pryse-Phillips WE, Chandra RK, Rose B. Anaphylactic reaction to methylprednisolone pulsed therapy for multiple sclerosis. Neurology. 1984;34:1119-21.

28. Goldstein DA, Zimmerman B, Spielberg SP. Anaphylactic response to hydrocortisone in children: a case report. Ann Allergy. 1985;55:599-600.

29. Peller JS, Bardana EJ Jr. Anaphylactoid reaction to corticosteroid: case review and review of the literature. Ann Allergy. 1985;54:302-5.

30. Nakamura H, Matsuse H, Obase Y, Mitsuta K, Tomari S, Saeki S, et al. Clinical evaluation of Anaphylactic reactions to intravenous corticosteroids in adult asthmatics. Respiration. 2002;69:309-13.

31. Sieck JO, al-Ohaly Y, Saour J, Khan M, Henriquez H. An Allergic reaction to IV methylprednisolone administration. Br J Clin Pract. 1990;44:723-5.

32. Rao KV, Andersen RC, O'Brien TJ. Successful renal transplantation in a patient with anaphylactic reaction to Solu-Medrol (methylprednisolone sodium succinate). Am J Med. 1982;72:161-3.

33. McNamara RM. Anaphylaxis after intravenous corticosteroid administration. J Emerg Med. 1986;4:213-5.

34. Burgdorff T, Venemalm L, Vogt T, Landthaler M, Stolz W. IgE-mediated anaphylactic reaction induced by succinate ester of methylprednisolone. Ann Allergy Asthma Immunol. 2002;89:425-8.

35. Fernandez de Corres L, Bernaola G, Urrutia I, Munoz D. Allergic dermatitis from systemic treatment with corticosteroids. Contact Dermatitis. 1990;22:104-6.

36. Clee MD, Ferguson J, Browning MC, Jung RT, Clark RA. Glucocorticoid hypersensitivity in an asthmatic patient: presentation and treatment. Thorax. 1985;40:477-8.

37. Pirker C, Misic A, Frosch PJ. Angioedema and dysphagia caused by contact allergy to inhaled budesonide. Contact Dermatitis. 2003;49:77-9.

38. Kilpio K, Hannuksela M. Corticosteroid allergy in asthma. Allergy. 2003;58:1131-5

39. Isaksson M, Bruze M, Hornblad Y, Svenonius E, Wihl JA 
Contact allergy to corticosteroids in asthma/rhinitis patients. Contact Dermatitis. 1999;40:327-8.

40. Valsecchi R, Reseghetti A, Leghissa P. Erythema-multiforme-like lesions from triamcinolone acetonide. Contact Dermatitis. 1998;38:362.

41. Amin N, Brancaccio R, Cohen D. Cutaneous reactions to injectable corticosteroids. Dermatitis. 2006;17:143-6.

42. Räsänen L, Hasan T. Allergy to systemic and intralesional corticosteroids. Br J Dermatol. 1993;128:407-11.

43. Pollock B, Wilkinson SM, MacDonald Hull SP. Chronic urticaria associated with intra-articular methylprednisolone. Br J Dermatol. 2001;144:1228-30.

44. Coopman S, Degreef H, Dooms-Goossens A. Identification of cross-reaction patterns in allergic contact dermatitis from topical corticosteroids. $\mathrm{Br} \mathrm{J}$ Dermatol. 1989;121:27-34.

45. Lepoittevin JP, Drieghe J, Dooms-Goossens A. Studies in patients with corticosteroid contact allergies. Arch Dermatol. 1995;131:31-7.

46. Goossens A, Matura M, Degreef H. Some new aspects regarding cross-sensitivity. Cutis. 2000;65:43-5.

47. Ferguson A, Emerson R, English J. Cross-reactivity patterns to budesonide. Contact Dermatitis. 2002; 47:337-40.

48. Boffa MJ, Wilkinson SM, Beck MH. Screening for corticosteroid contact hypersensitivity. Contact Dermatitis. 1995;33:149-51.

49. Seukeran DC, Wilkinson SM, Beck MH. Patch testing to detect corticosteroid allergy: is it adequate? Contact Dermatitis. 1997;36:127-30.

50. Wilkinson SM, Beck MH. Corticosteroid contact hypersensitivity; what vehicle and concentration? Contact Dermatitis. 1996;34:305-8.
51. Wilkinson SM, and Beck MH. Patch testing for corticosteroid allergy using high and low concentrations. Contact Dermatitis. 2000;42:350-1.

52. Chowdhury MM, Statham BN, Sanson JE, Foulds IS, English JS, Podmore P, et al. Patch testing for corticosteroid allergy with low and high concentrations of tixocortol pivalate and budesonide. Contact Dermatitis. 2002; 46:311-2.

53. Dooms-Goossens A, Degreef $\mathrm{H}$. Clinical aspects of con tact allergy to corticosteroids. Dermatology. 1994; 189(Suppl 2):S54-5.

54. Gebhardt M, Elsner P, Marks JG. Handbook of contact dematitis. London: Martin Dunits; 2000. p. 66.

55. Isaksson M. Corticosteroids. Dermatol Ther. 2004; 17:314-20.

56. Middleton E, Reed CE, Ellis EF. Allergy, principles \& practice. 5th ed. St. Louis: Mosby; 1998. p. 340-2.

57. Chew AL, Maibach HI. Multiple corticosteroid orally elicited allergic contact dermatitis in a patient with multiple topical corticosteroid allergic contact dermatitis. Cutis. 2000;65:307-11.

\author{
MAILING ADDRESS: \\ Ronald Brancaccio MD \\ 7901 Fourth Avenue \\ Brooklyn, NY 11209 \\ Telephone: 718-491-5800 \\ Fax: 718-748-2151 \\ Email: skinofny@aol.com
}

How to cite this article: Ramirez R, Brancaccio RR. Allergic cutaneous reactions to systemic corticosteroids. An Bras Dermatol. 2007;82(2):169-76. 